\title{
The genus Dasineura Rondani, 1840 (Diptera, Cecidomyiidae) in Brazil
}

\author{
Maia, $V C^{*}$. and Silva, LO. \\ Museu Nacional, Quinta da Boa Vista, São Cristóvão, CEP 20940-040 Rio de Janeiro, RJ, Brazil. \\ "e-mail:maiavcid@acd.ufrj.br \\ Received May 17, 2012 - Accepted November 27, 2012 - Distributed November 29, 2013
}

\begin{abstract}
Dasineura (Diptera, Cecidomyiidae) is the gall midge genus with the highest number of known species (466 throughout the world). Only 39 species have been described from the Neotropics, being 10 from Brazil. Many records of not determined species are found in the literature. Furthermore, many unidentified specimens are deposited in the Cecidomyiidae Collection of the Museu Nacional/UFRJ, which comprises material from several Brazilian biomes. This paper provides these data, presents new records of localities and host plants, and discusses the representativeness of Dasineura in Brazil. The results point to the occurrence of 32 species in Brazil and show that the genus is much more diversified than previous knowledge indicates.
\end{abstract}

Keywords: gall, insect-plant interaction, geographic distribution, new records.

\section{O gênero Dasineura Rondani, 1840 (Diptera, Cecidomyiidae) no Brasil}

\section{Resumo}

Dasineura (Diptera) é o gênero de Cecidomyiidae com o maior número de espécies conhecidas (466 no mundo). Apenas 39 espécies foram descritas da região Neotropical, sendo 10 do Brasil. Muitos registros de espécies não determinadas são encontrados em literatura. Além disso, muitos exemplares não identificados estão depositados na Coleção de Cecidomyiidae do Museu Naciona/UFRJ, que compreende material de diversos biomas brasileiros. Este artigo compila estas informações, apresenta novos registros de localidades e de plantas hospedeiras e discute a representatividade de Dasineura no Brasil. Os resultados assinalam a ocorrência de 32 espécies no Brasil e mostram que o gênero é muito mais diversificado do que o conhecimento prévio indica.

Palavras-chave: galha, interação inseto-planta, distribuição geográfica, novos registros.

\section{Introduction}

Dasineura Rondani, 1840 (Diptera, Cecidomyiidae) is the gall midge genus with the highest number of known species (466 throughout the world). The majority of the species have been described from the Paleartic region. Only 39 species are known from the Neotropics, and among them, 10 occur in Brazil. Dasineura is included in the Dasineurini tribe, which comprises seven more genera (Gagné, 2010). It is traditionally characterised by presenting: larva - two-toothed prothoracic spatula, six lateral papillae per side, and eight terminal papillae; adult - antennae with 15 flagellomeres, four-segmented palpi, toothed tarsal claws, and $\mathrm{R} 5$ joining $\mathrm{C}$ at least slightly before the wing apex; male - flagellomeres with marked necks, gonocoxites with mediobasal lobe that gradually tapers from base to abdominal tergite as long or longer than seventh and tending to divide longitudinally (Gagné, 1994). Nevertheless, Dasineura presents a great morphological variation and many species do not fit into the traditional definition. According to Gagné 2010,
Dasineura is a broadly defined polyphyletic genus, which explains such variation.

The aim of this work is to evaluate the diversity of Dasineura in Brazil, to determine the plant organs where galls are induced, to give an inventory of the host plant species, to verify the species richness by biomes, and to upgrade geographic distribution of the genus.

\section{Material and Methods}

The Museu Nacional/UFRJ comprises the unique reference collection of gall midges from Brazil. It includes material from several biomes: Amazonian forest, Atlantic forest, Caatinga, Cerrado and Pantanal. This collection was investigated to find Brazilian specimens of Dasineura. A literature survey was also carried out; data until 2010 were extracted from Gagné, 2010; data from 2010 to 2012 were obtained from "Thomson IS database", using Dasineura (title) and Brasil/Brazil (topic) as key words. This literature investigation was conducted in April, 2012. 
The information was organised in tables, the Brazilian species of Dasineura, host plants, galled organs, galls characterisation (shape, colour, and number of chamber), localities, biomes of occurrence, and references are presented.

\section{Results and Discussion}

Dasineura is represented by 32 species in Brazil, among them, ten are already known and 22 are not determined. Considering the high host specificity of the gall midges, the last ones probably belong to new species, as they are associated with new records of plants. Based on this specificity, we can include the undetermined species of Dasineura in the following discussion.

Dasineura is associated with 30 plant species and 14 plant families in Brazil. Myrtaceae and Asteraceae comprise the greatest richness of Dasineura species (12 and 07, respectively), followed by Malpighiaceae (02 spp.). The other families (Anacardiaceae, Bignoniaceae, Burseraceae, Chrysobalanaceae, Erythroxylaceae, Fabaceae, Melastomataceae, Ochnaceae, Rubiaceae, Solanaceae, and Symplocaceae) are associated each with a single species of Dasineura (as shown in Table 1). Eugenia L. (Myrtaceae) and Chromolaena DC. (Asteraceae) were the most important host plant genera, with six and four species of Dasineura, respectively.

Table 1 - Distribution of the number of Dasineura species (Diptera, Cecidomyiidae) per host plant families and species in Brazil.

\begin{tabular}{|c|c|c|}
\hline \multicolumn{2}{|l|}{ Host plant } & \multirow{2}{*}{$\begin{array}{l}\text { Number of Dasineura } \\
\text { species }(\mathrm{n}=32)\end{array}$} \\
\hline Family $(n=14)$ & Species $(n=30)$ & \\
\hline \multirow[t]{2}{*}{ Anacardiaceae } & Tapirira guianensis Aubl. & 01 \\
\hline & Total & 01 \\
\hline \multirow[t]{8}{*}{ Asteraceae } & Chromolaena chaseae (B.L. Tob.) R.M. King \& H. Rob. & 01 \\
\hline & Chromolaena pedunculosa (Hook. \& Arn.) R.M. King \& H. Rob. & 01 \\
\hline & Chromolaena pungens (Hook. \& Arn.) R.M. King \& H. Ron. & 01 \\
\hline & Chromolaena squalida (DC.) R.M. King \& H. Rob. & 01 \\
\hline & Emilia sonchifolia $(\mathrm{L}$.$) DC.$ & 01 \\
\hline & Gochnatia barrosii Cabrera & 01 \\
\hline & Gochnatia pulchra Cabrera & 01 \\
\hline & Total & 07 \\
\hline \multirow[t]{2}{*}{ Bignoniaceae } & Macfadyena unguis-cati (L.) A. H. Gentry & 01 \\
\hline & Total & 01 \\
\hline Burseraceae & Protium heptaphyllum (Aubl.) Marchand & 01 \\
\hline \multirow[t]{2}{*}{ Chrysobalanaceae } & Couepia ovalifolia (Schott) Benth. & 01 \\
\hline & Total & 01 \\
\hline \multirow[t]{2}{*}{ Erythroxylaceae } & Erythroxylum ovalifolium Peyr. & 01 \\
\hline & Total & 01 \\
\hline Fabaceae & Stryphnodendron sp. & 01 \\
\hline \multirow[t]{3}{*}{ Malpighiaceae } & Byrsonima sericea DC. & 01 \\
\hline & Heteropterys nitida DC. & 01 \\
\hline & Total & 02 \\
\hline \multirow[t]{2}{*}{ Melastomataceae } & Not determined & 01 \\
\hline & Total & 01 \\
\hline \multirow[t]{5}{*}{ Myrtaceae } & Eugenia copacabanensis Kiaersk. & 02 \\
\hline & Eugenia florida DC. & 01 \\
\hline & Eugenia rotundifolia Casar & 01 \\
\hline & Eugenia umbelliflora $\mathrm{O}$. Berg and E. rotundifolia & 01 \\
\hline & Eugenia uniflora $\mathrm{L}$. & 01 \\
\hline
\end{tabular}


Table 1 - cont.

\begin{tabular}{|c|c|c|}
\hline \multicolumn{2}{|l|}{ Host plant } & \multirow{2}{*}{$\begin{array}{c}\text { Number of Dasineura } \\
\text { species }(\mathrm{n}=32)\end{array}$} \\
\hline Family $(n=14)$ & Species $(\mathbf{n}=\mathbf{3 0})$ & \\
\hline & Myrcia ovata Cambess. & 01 \\
\hline & Myrciaria floribunda (H. West ex Willd.) O. Berg & 01 \\
\hline & Neomitranthes obscura (DC.) N. Silveira & 01 \\
\hline & Psidium cattleianum Sabine & 01 \\
\hline & Siphoneugeia reitzii D. Legrand & 01 \\
\hline & Not determined & 01 \\
\hline & Total & 12 \\
\hline \multirow[t]{2}{*}{ Ochnaceae } & Ouratea hexasperma (A. St.-Hil.) Baill. & 01 \\
\hline & Total & 01 \\
\hline \multirow[t]{2}{*}{ Rubiaceae } & Psychotria leiocarpa Cham. \& Schltdl. & 01 \\
\hline & Total & 01 \\
\hline \multirow[t]{2}{*}{ Solanaceae } & Capsicum sp. & 01 \\
\hline & Total & 01 \\
\hline \multirow[t]{2}{*}{ Symplocacaeae } & Symplocos uniflora (Pohl) Benth. & 01 \\
\hline & Total & 01 \\
\hline
\end{tabular}

Eugenia copacabanensis Kiaersk, (Myrtaceae) was the unique plant species that comprised more than one species of Dasineura. According to Gagné, 2010, Dasineura is associated with 65 plant families in the world, being more frequent on Fabaceae, Asteraceae, and Rosaceae. These families comprise 69,42 and 35 species of Dasineura, respectively, while Myrtaceae comprise only seven species. In our study, Asteraceae are also pointed out as an important host plant family, but this is not the case for Fabaceae, and Rosaceae. Another difference is that Myrtaceae are indicated as the most important host.

Most species (94\%) were gall-inducers, and only two were free-living. The majority of the species occurred on leaves ( $43 \%$ or $14 \mathrm{spp}$.), two on buds, three on flower buds, one on a stem, and one on leaves and stem. The plant organs were not specified for 11 species of Dasineura (as shown in Table 2). The galls were classified as simple (08 morphotypes) or complex 06 (morphotypes), according to Möhn (1961) (16 morphotypes

Table 2 - Distribution of the number of Dasineura species (Diptera, Cecidomyiidae) per plant organs in Brazil.

\begin{tabular}{lc}
\hline Plant organ & Number of Dasineura species $(\mathbf{n}=\mathbf{3 2})$ \\
\hline Leaves & 14 \\
Flower buds & 03 \\
Buds & 02 \\
Stems & 01 \\
Leaves and stem & 01 \\
No data & 11 \\
\hline
\end{tabular}

cannot be classified due to the lack of information). According to Gagné, 2004 Dasineura includes free-living species as well as species that form simple or complex galls.

Many gall shapes were found: globose, ovoid, rosette, marginal roll, discoid, conical and fusiform.

Table 3 - Distribution of the number of Dasineura species (Diptera, Cecidomyiidae) per Brazilian biomes.

Brazilian biome Number of Dasineura species $(\mathrm{n}=32)$

\begin{tabular}{ll}
\hline Atlantic forest & 20 \\
Cerrado & 10 \\
Cultivated plants & 02 \\
\hline
\end{tabular}

Table 4 - Distribution of the number of Dasineura species (Diptera, Cecidomyiidae) per Brazilian states.

\begin{tabular}{lc}
\hline Brazilian state & Number of Dasineura species \\
\hline Pernambuco & 01 \\
Bahia & 01 \\
Distrito Federal & 01 \\
Minas Gerais & 01 \\
Rio de Janeiro & 12 \\
São Paulo & 12 \\
Paraná & 01 \\
Santa Catarina & 01 \\
Rio Grande do Sul & 01 \\
\hline
\end{tabular}




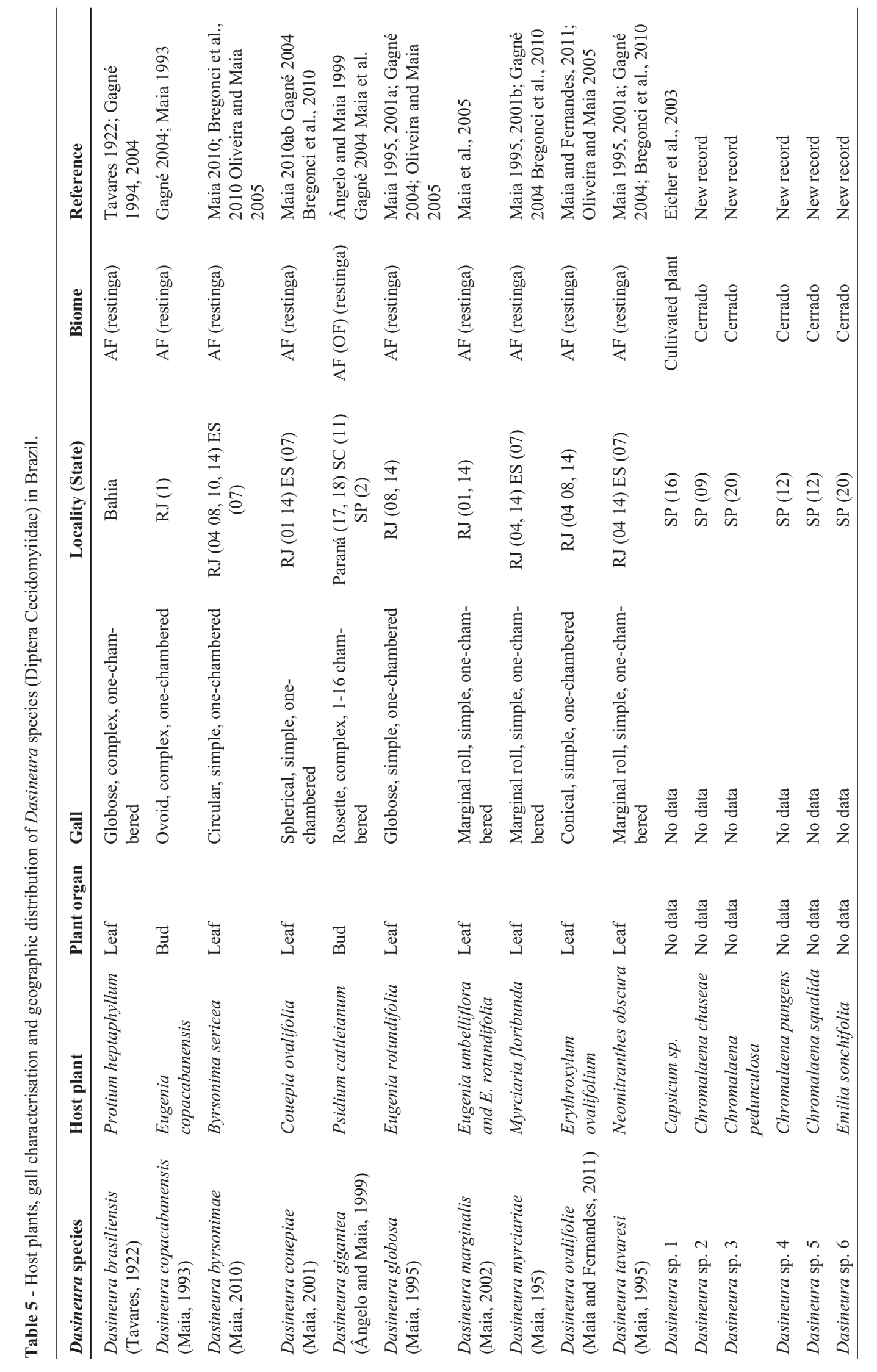


Dasineura (Diptera, Cecidomyiidae) in Brazil

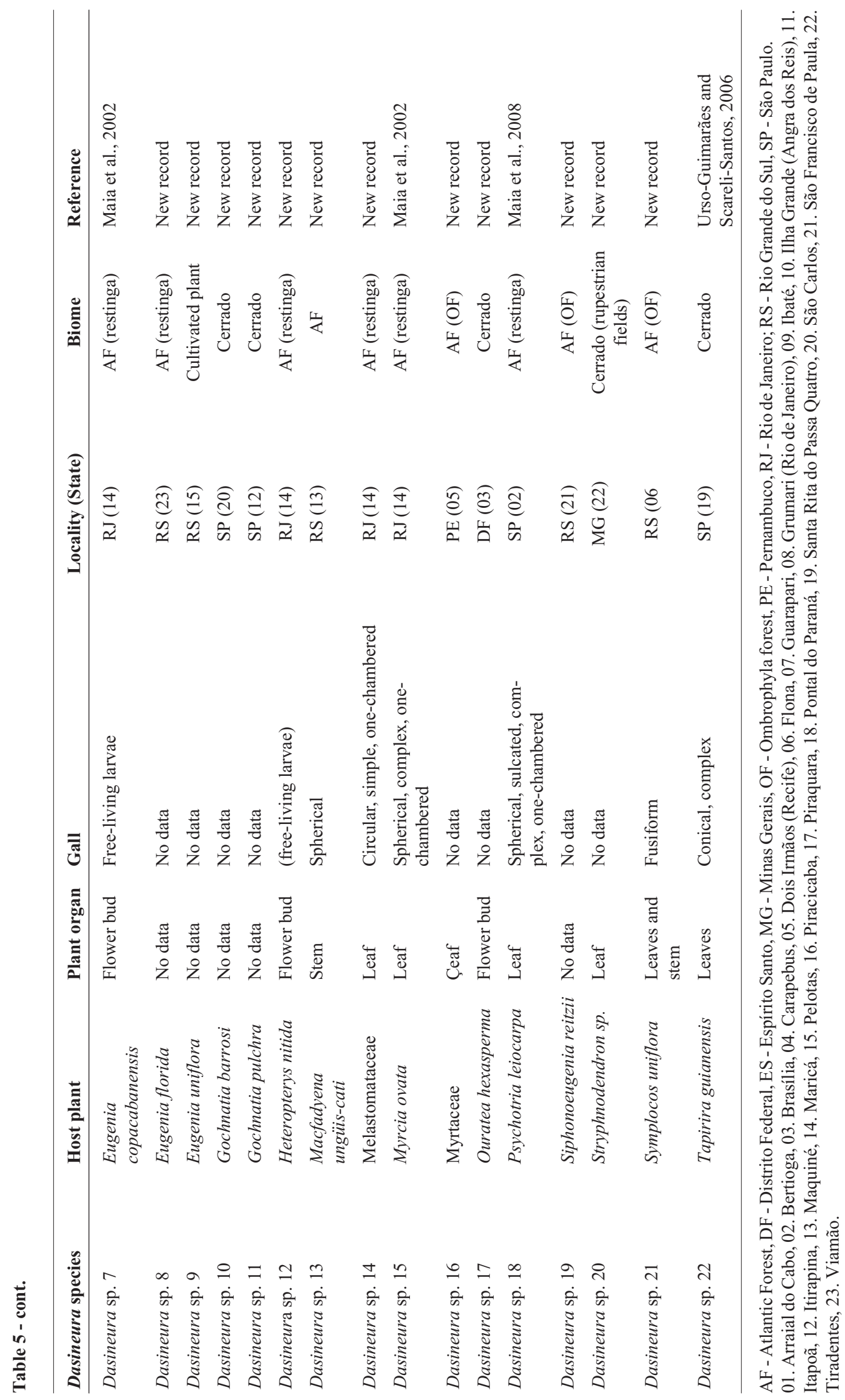


Twelve gall morphotypes were one-chambered, a single morphotype presented from one to 16 chambers. All chambers were occupied by a single galling larva. There is no data for the other galls.

The genus was found in two biomes, Atlantic forest (20 spp.) and cerrado (10 spp.). Two species were found in cultivated plants ( $02 \mathrm{spp}$.) (as shown in Table 3 ). The species from Atlantic forest were found mainly in restinga areas (16 spp., being 15 exclusive).

The species were collected in Pernambuco (01 sp.), Bahia (01 sp.), Distrito Federal (01 sp.), Minas Gerais (01), Espírito Santo (04), Rio de Janeiro (12 spp.), São Paulo (11 spp.), Paraná (01 sp.), Santa Catarina (01 sp.), and Rio Grande do Sul (05 spp.) (as shown in Table 4). The majority of the species were collected in Rio de Janeiro and São Paulo, the best surveyed states. Although Minas Gerais is a well investigated area, it comprises only one Dasineura species. The other states have been less surveyed. The records for Recife (Pernambuco), Brasília (Distrito Federal), Itirapina, Ibaté, São Carlos (São Paulo), Tiradentes (Minas Gerais), Flona, Maquiné, Pelotas, São Francisco de Paula and Viamão (Rio Grande do Sul) are new.

The following plants are recorded for the first time as host plants of Dasineura species: Heteropterys nitida DC. (Malpighiaceae), Ouratea hexasperma (A. St.-Hil.) Baill. (Ochnaceae), Macfadyena ugüis-cati cati (L.) A. H. Gentry (Bignoniaceae), Stryphnodendron sp. (Fabaceae), Siphoneugenia reitzii D. Legrand (Myrtaceae), Symplocos uniflora (Pohl) Benth. (Symplocaceae), Chromolaena chaseae (B.L. Rob. R.M. King \& H. Rob. (Asteraceae), Chromolaena pedunculosa (Hook. \& Arn.) R.M. King \& H. Rob. (Asteraceae), Chromolaena pungens (Hook. \& Arn.) R.M. King \& H. Rob. (Asteraceae), Chromolena squalid (DC.) R.M. King \& H. Rob. (Asteraceae), and Emilia sonchifolia (L.) DC. (Asteraceae).

Table 5 summarises data of geographic distribution of the species and presents the attacked plant organ, as well as a brief gall characterisation (based on shape and number of internal chamber).

Dasineura couepiae Maia, 2001, D. gigantea Maia, 1995, D. myrciariae Maia, 1995, D. byrsonimae Maia, 2010, and D. ovalifoliae Maia and Fernandes, 2011 are described as larva, pupa, male, and female. The larvae of $D$. globosa and D. marginalis, the pupa of $D$. copacabanensis, the male of $D$. tavaresi, and the pupa and male of $D$. brasiliensis are still unknown. The morphology of the last species is partially known, so new collections of galls and gall maker rearing are necessary to complete the species characterisation.

As Dasineura is polyphyletic, phylogenetic studies are necessary to define the limits of the genus. Gagné, 2010 suggested that Dasineurini on Fabaceae and Brassicaceae can be separate monophyletic groups, and added that "no groupings within Dasineurini can be satisfactory until the tribe is revised in a comprehensive way".

\section{Conclusions}

Dasineura is poorly known in Brazil, where it includes 22 undescribed species and four partially described ones. Data on attacked plant organs is lacking for 11 species.

In Brazil, the most important host plant families are Myrtaceae and Asteraceae. The importance of the latter was pointed out by Gagné, 2010, but the former is indicated thus for the first time.

The records of free-living and galling species confirm the known feeding habits of the larva.

The majority of the species was recorded in two biomes: Atlantic forest and cerrado. Little information is available for the other Brazilian biomes. The best investigated localities are Rio de Janeiro and São Paulo. Few records are known for other Brazilian states. So it is necessary to investigate other localities and biomes to understand the geographic distribution of Dasineura spp. as well as the diversity of each biome.

Acknowledgments - The authors would like to thank CNPq (VCM, Proc. 300237/2010-3) and FAPERJ (LOS, Proc. E-26/100.377/2011) for financial support.

\section{References}

ÂNGELO, AC. and MAIA, VC., 1999. Dasineura gigantea sp.n. (Diptera, Cecidomyiidae) associada a Psidium cattleianum Sabine (Myrtaceae) no Brasil. Revista brasileira da Zoologia, vol. 16, no. 1, p. 1991-195.

BREGONCI, JM., POLYANNA, VP. and MAIA, VC., 2010. Galhas de insetos do Parque Estadual Paulo César Vinha (Guarapari, ES, Brasil). Biota Neotropica, vol. 10, no. 1, p. 1-10.

ECHER, MM., GUIMARÃES, VF. and MINAMI, K., 2003. Damage occurence and determination of Dasineura sp. (Diptera: Cecidomyiidae) in cultivar (Capsicum annuum L.) in Piracicaba. Acta Horticulturae, vol. 607, p. 159161.

GAGNÉ, RJ., 1994. The gall midges of the Neotropical region. Ithaca: Cornell University Press. 352 p.

GAGNÉ, RJ., 2004. A catalog of the Cecidomyiidae (Diptera) of the world. Memoirs of the Entomological Society of Washington, vol. 25, p. 1-409.

GAGNÉ, RJ., 2010. Update for a catalog of the Cecidomyiidae (Diptera) of the world. Digital version 1. Available from: http://www.ars.usda.gov/SP2UserFiles/ Place/12754100/ Gagne_2010_World_Catalog_Cecidomyiidae.pdf.

MAIA, VC., 1993. Descrição de duas espécies novas de Cecidomyiidae (Diptera) associadas a Eugenia spp. (Myrtaceae). Revista Brasileira de Entomologia, vol. 37, no. 4, p. 717-721.

MAIA, VC., 1995. Três espécies novas de Dasineura Rondani (Diptera, Cecidomyiidae) associadas a Myrtaceae na restinga da Barra de Maricá, Rio de Janeiro. Revista brasileira de Zoologia, vol. 12, no. 4, p. 1000-1008.

MAIA, VC., 2001a. The gall midges (Diptera, Cecidomyiidae) from three restingas of Rio de Janeiro State, Brazil. Revista brasileira de Zoologia, vol. 18, no. 2, p. 583-629.

MAIA, VC., 2001b. New genera and species of gall midges (Diptera, Cecidomyiidae) from three restingas of Rio de Janeiro State, Brazil. Revista brasileira de Zoologia, vol. 18 , p. 1-32. 
MAIA, VC., 2010. A new species of Dasineura Rondani, 1840 (Diptera, Cecidomyiidae) associated with Byrsonima sericea (Malpighiaceae). Revista brasileira de Biociências, vol. 8, no. 4, p. 377-380.

MAIA, VC. and FERNANDES, GW., 2004. Insect galls from Serra de São José (Tiradentes, MG, Brazil). Brazilian Journal of Biology, vol. 64, no. 3a, p. 423-445.

MAIA, VC. and FERNANDES, SPC., 2011. Two new species of gall midges (Diptera, Cecidomyiidae) associated with Erythroxylum ovalifolium Peyr. (Erythroxylaceae) from the Barra de Maricá restinga, Maricá, Rio de Janeiro, Brazil. Brazilian Journal of Biology, vol. 71, no. 2, p. $521-526$

MAIA, VC. and OLIVEIRA, JC., 2010. Galhas de insetos da Reserva Biológica Estadual da Praia do Sul (Ilha Grande, Angra dos Reis, RJ). Biota Neotropica, vol. 10, no. 4, p. $227-237$.

MAIA, VC., AZEVEDO, MAP. and COURI, MS., 2002. New contribution to the knowledgeof the gall midges (Diptera, Cecidomyiidae) from the restinga of Barra de Maricá (Rio de Janeiro, Brazil). Studia Dipterologica, vol. 9, no. 2, p. 447-452.
MAIA, VC., CONSTANTINO, PAL. and MONTEIRO, RF., 2005. New gall midges (Diptera, Cecidomyiidae) associated with two species of Eugenia (Myrtaceae). Revista Brasileira de Entomologia, vol. 49, no. 3, p. 347-352.

MAIA, VC., MAGENTA, MAG. and MARTINS, SE., 2008. Ocorrência e caracterização de galhas de insetos em áreas de restinga de Bertioga (São Paulo, Brasil). Biota Neotropica, vol. 8, no. 1, p. 167-197.

MÖHN, E., 1961b. Gallmücken (Diptera, Itonididae) aus El Salvador. 4. Zur Phylogenie der Asphondyliidi der neotropischen und holarktischen Region. Senckenbergiana Biologica, vol. 42, p. 131-330.

OLIVEIRA, JC. and MAIA, VC., 2005. Ocorrência e caracterização de galhas de insetos na restinga de Grumari (Rio de Janeiro, RJ, Brasil). Arquivos do Museu Nacional, vol. 63 , no. 4, p. 669-675.

TAVARES, JS., 1922. Cecidologia brazileira. As restantes famílias. Brotéria, Série Zoologica, vol. 20, p. 5-48.

URSO-GUIMARÃES, MV. and SCARELI-SANTOS, C., 2006. Galls and gall makers I plants from the Pé-deGigante Cerrado Reserve, Santa Rita do Passa Quatro, SP, Brazil. Brazilian Journal of Biology, vol. 66, no. 1B, p. 357-369. 